Advance Journal of Food Science and Technology 14(5): 148-154, 2018

DOI:10.19026/ajfst.14.5912

ISSN: 2042-4868; e-ISSN: 2042-4876

(C) 2018 Maxwell Scientific Publication Corp.

Submitted: April 18, 2018

Accepted: May 9, 2018

Published: August 25, 2018

\title{
Research Article \\ Evaluation of Antioxidant Activity of Egg White Hydrolysates and Their Application on Color Stability of Pork Meat Slices
}

\author{
${ }^{1}$ Yu Wang, ${ }^{2}$ Jufang Shen and ${ }^{1}$ Hajime Hatta \\ ${ }^{1}$ Department of Food and Nutrition, Kyoto Women's University, Kyoto, 605-8501, Japan \\ ${ }^{2}$ Department of Research, China Jilin Jinyi Egg Products Co., Ltd., Dongliao Modern Agricultural and \\ Technology Industrial Park, Jilin 136200, China
}

\begin{abstract}
In this study, we assessed the antioxidant efficacy of four different size distributions of Egg White (EW) hydrolysates and evaluated their potential as natural antioxidants for meat preservation. Water solubility and Oxygen Radical Absorbance Capacity (ORAC) of EW hydrolysates were measured. Hydrolysis contributed to the increase of ORAC values of EW hydrolysates in comparison with native egg white. Based on this result, we investigated the effects of EW hydrolysates on color stability of pork slices. Pork slices were individually soaked in four EW hydrolysates solutions at $10 \%(\mathrm{w} / \mathrm{w})$ protein concentration. After storage at $4{ }^{\circ} \mathrm{C}$ for $24 \mathrm{~h}$, objective measurements of the color of pork slices were performed using a colorimeter, the content of metmyoblobin before and after soak was also determined. Small size EW hydrolysate $\mathrm{S}$ showed a good ORAC value $(389 \mu \mathrm{mol} \mathrm{TE} / \mathrm{g})$ and an excellent water solubility, inhibited color change $(\Delta \mathrm{E}=2.8)$ in treated pork slices, the lowest metmyoglobin proportion was also found in the meat treated by this small size EW hydrolysate S. Moreover, it was demonstrated that EW hydrolysates were generally better than the Control (only with water) in improving color stability during storage time. These results indicate that EW hydrolysates are promising sources of biological antioxidants and can potentially be used as preservatives in meat products.
\end{abstract}

Keywords: Antioxidant activity, color stability, egg white hydrolysate, metmyoglobin, pork meat

\section{INTRODUCTION}

Lipid oxidation is a major cause of meat food deterioration, affecting color, flavor, texture and nutritional value (Mansour and Khalil, 2000). It was reported that $74 \%$ of consumers indicated that meat color, accelerated by lipid oxidation is one of the major quality parameters affecting their decisions to purchase meat, because they regarded bright red color as freshness (Lynch et al., 1986; Ismail et al., 2009). It is known that the red color of meat depends upon the concentration of myoglobin and its derivatives (Faustman et al., 1992; Hood, 1980). Metmyoglobin is the state when the iron has oxidized and is shows tan or brown in color.

Application of antioxidants is the best strategy to prevent oxidation reactions in the food industry (Shahidi, 2000). Addition of antioxidants to different meat products for prevention lipid oxidation, retarded development of off-flavorsand improved color stability, such as BHA (Butylated Hydroxyanisole), BHT (Butylated Hydroxytoluene), PG (Propyl Gallate) and TBHQ (tert-butylhydro qui-none) (Kumar et al., 2015).
But because of adverse attention received by synthetic antioxidants and also due to the worldwide trend to avoid or minimize use of artificial (synthetic) food additives, the potential of natural antioxidants in preventing lipid oxidation in food products has been evaluated by many researchers around the world during last few years (Hashemi et al., 2017).

Nasri et al. (2013) concluded that incorporation of protein hydrolyzates prepared from Goby fish (Zosterisessorophiocephalus) could delay lipid oxidation in turkey meat sausage. Kim et al. (2013) assessed the antioxidant efficacy of 10 leafy edible plants and investigated the effects of butterbur and broccoli extracts on lipid oxidation in ground beef patties, the beef patties formulated with the selected plant extracts showed significantly $(p \leq 0.05)$ better color stability than those without antioxidants. Mansour and Khalil (2000) proved that additions of freeze-dried extracts from ginger rhizomes and fenugreek seeds to beef patties were more effective than potato peel extract in controlling lipid oxidation and color changes during cold storage.

Corresponding Author: Hatta Hajime, Department of Food and Nutrition, Kyoto Women's University, 605-8501, Kyoto, Japan, Tel.: 81-75-531-7143; Fax: 81-75-531-7170

This work is licensed under a Creative Commons Attribution 4.0 International License (URL: http://creativecommons.org/licenses/by/4.0/). 
Table 1: Working condition of enzymes

\begin{tabular}{llll}
\hline Product name of protease & Proteolytic activity of enzyme & Optimal temperature and $\mathrm{pH}$ & $\begin{array}{l}\text { Enzyme Inactivation } \\
\text { temperature } / \mathrm{T}^{\circ} \mathrm{C}\end{array}$ \\
\hline Protin $\mathrm{NY} 100^{\circledR}$ & $900,000 \mathrm{U} / \mathrm{g}$ & $50^{\circ} \mathrm{C} ; \mathrm{pH} \mathrm{7.0}$ & $65-70^{\circ} \mathrm{C}$ \\
ThermoasePC $10 \mathrm{~F}^{\circledR}$ & $700,000 \mathrm{U} / \mathrm{g}$ & $65^{\circ} \mathrm{C} ; \mathrm{pH} \mathrm{7.5}$ & $85-90^{\circ} \mathrm{C}$ \\
Protease $\mathrm{M}^{\otimes}$ & $40,000 \mathrm{U} / \mathrm{g}$ & $50^{\circ} \mathrm{C} ; \mathrm{pH} 6.0$ & $60-70^{\circ} \mathrm{C}$ \\
\hline
\end{tabular}

Egg proteins are nutritionally complete with a good balance of essential amino acids which are needed for building and repairing the cells in muscles and other body tissues (Watkins, 1995). Nowadays, many researchers have unlocked the hidden biological functions of peptides in egg proteins such as antihypertensive (Miguel and Aleixandre, 2006), anticancer (Moon et al., 2013; Ibrahim and Kiyono, 2009) or exaggerated antimicrobial activities (Ibrahim et al., 2000). EW is also known as a desirable ingredient in many foods such as bakery products, meringues and meat products in which it is mainly used for its excellent gelling and foaming properties.

In this study, we assessed the antioxidant efficacy of hydrolysates of EW proteins with four different size distributions, evaluated their potential as natural antioxidants for meat preservation, especially its effect on preventing or reducing color changes of pork meat stored at $4^{\circ} \mathrm{C}$.

\section{MATERIALS AND METHODS}

Preparation of egg white hydrolysates: Three kinds of enzymes: Protin $\mathrm{NY}_{100}{ }^{\circledR}$, Thermoase $\mathrm{PC} 10 \mathrm{~F}^{\circledR}$, Protease $\mathbf{M}^{\circledR}$, which were provided by Amano Enzyme Inc. (Japan) were used in this study, EW hydrolysates obtained using these three enzymes were named: PNY, $\mathrm{T}$ and $\mathrm{PM}$, respectively. Optimal $\mathrm{pH}$ and temperature for each enzyme were listed in Table 1.

Hen eggs were obtained from a local supermarket (Kyoto, Japan) and were manually broken and separated yolk from EW. EW was mixed using a hand mixer (National MK-210, Japan) at a rotational speed of $540 \mathrm{rpm}$ for $3 \mathrm{~s}$, then filtered by passing through a stainless mesh (sieve size $0.60 \mathrm{~mm}$ ), any foam was removed. The $\mathrm{pH}$ of EW was adjusted to each optimal working $\mathrm{pH}$ as shown in Table 1 with $10 \%$ (w/v) citric acid solution before using for the experiment.

The enzyme was added at a concentration of $0.4 \%$ (w/w) after EW being warmed up to $50^{\circ} \mathrm{C}$. Enzymatic treatments were conducted as follows: $10 \mathrm{~min}$ at $50^{\circ} \mathrm{C}$, then adjusted to its corresponding optimal working temperature and maintained for $30 \mathrm{~min}$ before inactivation. Inactivation of the enzyme was achieved by holding the resulting hydrolysates at $90^{\circ} \mathrm{C}$ for $8 \mathrm{~min}$, before homogenization by a mechanical homogenizer (IKA T18 basic, Germany) at Dial 5 (15,000 rpm) for 60 s. EW hydrolysates were then freeze-dried (FreeZone Plus 12 Liter Cascade Console Freeze Dry System, Labconco, Japan) and stored as powder at $30^{\circ} \mathrm{C}$ in a Biomedical Freezer (MDF-U539-PJ, Panasonic, Japan).
Peptide $\mathrm{S}$ is a mixture of EW peptides with molecular weight lower than $10 \mathrm{kDa}$ (as reported in the product description) provided by Pharma Foods International Co. Ltd, Japan. Peptide S (80\% proteins) was dissolved in distilled water at a concentration of $100 \mathrm{mg}$ (protein) $/ \mathrm{mL}$ as a reference sample, which was then stored at $4^{\circ} \mathrm{C}$ until use.

Determination of hydrolysis degree: EW hydrolysate powder was dissolved in distilled water at a concentration of $100 \mathrm{mg} / \mathrm{mL}$ before determination of the Degree of Hydrolysis (DH). Free amino groups were quantified using the o-phthalaldehyde (OPA) micromethod described by Church et al. (1983) and with modifications by Darrouzet-Nardi et al. (2013).

SDS-PAGE: Sodium dodecyl sulfate polyacrylamide gel electrophoresis (SDS-PAGE) was performed according to Laemmli (1970). Pre-cast gels of 5-20\% acrylamide (C-520L, Atto Corporation, Tokyo, Japan) and protein ladder (WSE-7020, Atto Corporation, Tokyo, Japan) with the molecular weight from $10 \mathrm{kDa}$ to $245 \mathrm{kDa}$ were used.

Solubility: An aqueous solution (approximately 1.0\%, $w / v)$ of freeze-dried samples in deionized water was stirred magnetically for $30 \mathrm{~min}$. And then it was centrifuged at 13,500 rpm for $30 \mathrm{~min}$ at $4^{\circ} \mathrm{C}$ (CFRXII, Hitachi, Japan). After an appropriate dilution with deionized water, the protein content of supernatant was determined by the method of Markwell et al. (1978) using ovalbumin as a standard. The soluble protein percentage was expressed as $\mathrm{s}$ (protein content of the supernatant) / (sample protein content)*100.

ORAC-FL assay: The ORAC-FL assay was based on the method proposed by $\mathrm{Ou}$ et al. (2001) and was modified as previously described by Davalos et al. (2004). Samples prepared in $75 \mathrm{mM}$ phosphate buffer (pH 7.4) were mixed with $50 \mu \mathrm{L}$ of fluorescein $(200$ $\mathrm{nM})$ and incubated at $37^{\circ} \mathrm{C}$ for $10 \mathrm{~min}$. Trolox $(2-16$ $\mu \mathrm{M})$ was used as the standard. Then $50 \mu \mathrm{L}$ of $2,2^{\prime}-$ azobis(2-amidinopropane) dihydrochloride (AAPH) (80 $\mathrm{mM}$ ) as oxygen radical generator was added to each well using an automated dispenser and the plate was automatically shaken for $5 \mathrm{~s}$. Fluorescence was recorded using a fluorometric microplate reader (Infinite M200, TECAN, Switzerland) at 1 min interval for $60 \mathrm{~min}$ at excitation and emission wavelengths of 485 and $538 \mathrm{~nm}$, respectively.

All reaction mixtures were prepared in triplicate and at least three independent runs were performed for 
each sample. Measurements of fluorescence were normalized to the curve of the blank (no antioxidant). The net AUC of the sample was calculated by subtracting the AUC of the blank. ORAC-FL values were expressed as Trolox equivalents by using the standard curve calculated for each assay. Final ORACFL values were expressed as micromoles of Trolox equivalent per gram of protein for EW hydrolysate.

Treatment of pork slices by hydrolyzed egg white: Approximately $8 \mathrm{~cm} \times 6 \mathrm{~cm}$ of lean pork (leg meat) slices with a thickness of $4 \mathrm{~mm}$ were supplied by a local butcher shop (Kyoto, Japan). Fresh meat pH was determined as described by Pigott et al. (2000). Each piece of pork was weighed and then soaked individually in the same weight of EW hydrolysates solution (protein concentration of $10 \%, \mathrm{w} / \mathrm{w}$ ) in a zipper freezer bag, then it was stored in a fridge at $4{ }^{\circ} \mathrm{C}$ for $24 \mathrm{~h}$ until further analysis.

Color measurement: Objective measurements of color were performed using a CR 400 colorimeter (Minolta, Osaka, Japan). Each slice of meat was cut and the color of the slices was measured three times for each point. A portable colorimeter with the settings: pulsed xenon arc lamp, 0 viewing angle geometry and aperture size $8 \mathrm{~mm}$ was used to measure meat color in the CIELAB space (L: lightness; a: redness; b: yellowness,). Before each series of measurements, the instrument was calibrated using the reference white ceramic tile.

Total color change and \% color change were calculated according to the following formula (Ünal et al., 2014):

$$
\Delta E *=\sqrt{\Delta \mathrm{L} *^{2}+\Delta \mathrm{a} *^{2}+\Delta \mathrm{b} *^{2}}
$$

Relative proportions of myoglobin redox forms: Pigments in pork samples were extracted according to the method of Jun et al. (1999) with some modifications (Viriyarattanasak et al., 2011). The sample (2 g) was first minced in a pre-cooled mortar and then placed into a $50-\mathrm{mL}$ polypropylene centrifuge tube and $20 \mathrm{~mL}$ icecold phosphate buffer $\left(\mathrm{pH} 6.8,40 \mathrm{mM}, 4^{\circ} \mathrm{C}\right)$ was added. The mixture was homogenized with a mechanical homogenizer (IKA T18 basic, Germany) at Dial 5 (15,000 rpm) for $20 \mathrm{~s}$. The homogenized sample was centrifuged at $6,000 \mathrm{~g}$ for $30 \mathrm{~min}$ at $4^{\circ} \mathrm{C}$ (CFRXII, Hitachi, Japan). In order to avoid any turbidity of the extracts, the supernatant was filtered with a filter paper (Number 2, Advantec, Toyo, Japan), the absorption at $525,545,565$ and $572 \mathrm{~nm}$ of $\mathrm{Mb}$ derivatives were measured using a UV-vis spectrophotometer (U-2001, Hitachi, Japan).

The relative concentrations of metmyoglobin were calculated using the followed equations. Measurements were performed in triplicate:
$\%$ metmyoglobin $=\left(-2.514 \mathrm{R}_{1}+0.777 \mathrm{R}_{2}+0.800 \mathrm{R}_{3}+\right.$ 1.098) $\times 100$

While $R_{1}=A_{572 ~ n m} / A_{525} \mathrm{~nm}, R_{2}=A_{565} \mathrm{~nm} / A_{525} \mathrm{~nm}, R_{3}=$ $\mathrm{A}_{545 \mathrm{~nm}} / \mathrm{A}_{525 \mathrm{~nm}}$.

Statistic analysis: All experiments were carried out in triplicates. The data were subjected to multifactor Analysis of Variance (ANOVA), followed by the Least Significant Difference (LSD) test to determine the significant difference between samples at $\mathrm{p}<0.05$ level using the software SPSS V.16.

\section{RESULTS AND DISCUSSION}

Enzymatic digestion of egg white: Enzymatic hydrolysis contributes to the improvement of the nutritional, functional, immunological and biological activity of proteins (Bkhairia et al., 2016; Cheison et al., 2009) and DH is an important parameter to establish the relationship between proteolysis and the improvement of the functional, bioactive and sensory properties (Cheison et al., 2009). When analyzed by SDS-PAGE, EW proteins presented a wide range of molecular masses and concentrations. The main EW proteins: Ovalbumin $(44.5 \mathrm{kDa})$, ovotransferrin $(77.7$ $\mathrm{kDa})$, ovomucoid (28 kDa) and lysozyme (14.3 kDa), constitute $54,12,11$ and $3.4 \%$ of the total EW proteins, respectively (Abeyrathne et al., 2013). As observed in Fig. 1, Peptide $\mathrm{S}$ was hydrolyzed the most, with an average molecular weight less than $10 \mathrm{kDa}$. The band around $75 \mathrm{kDa}$ disappeared completely, which suggested that ovotransferrin could be hydrolyzed easier by Protin $\mathrm{NY} 100^{\circledR}$, Thermoase $\mathrm{PC} 10 \mathrm{~F}^{\circledR}$ as well as Protease $\mathbf{M}^{\circledR}$ than albumin. After passing through $0.45 \mu \mathrm{m}$ of the filter, most bands between $35 \mathrm{kDa}$ to 45 $\mathrm{kDa}$ were still visible. Most bands for EW hydrolysates obtained by Thermoase disappeared after filtration, that means the percentage of water-soluble protein in these three samples are low, which is in accordance with the result of solubility measurement shown in Fig. 2.

Antioxidant activity (ORAC value) of egg white hydrolysates: ORAC value was expressed as micromoles of trolox equivalent per gram of protein. Egg proteins are a source of biological active peptides. In the current study, after the breakdown of protein, EW hydrolysates except for PM showed relative higher ORAC values compared to NEw, suggesting that, hydrolysis by using certain enzymes should be one of the effective ways for EW protein to obtain antioxidative capacity. Moreover, as shown in Fig. 3, PNY and Peptide $\mathrm{S}$ exhibited relative higher ORAC values compared with the others. Combined with results showed by SDS-PAGE, as well as data of DH, Peptide $\mathrm{S}$ was the most hydrolyzed among all the samples. Chen et al. (2012) investigated antioxidative activities of EW protein hydrolysate prepared with trypsin at 


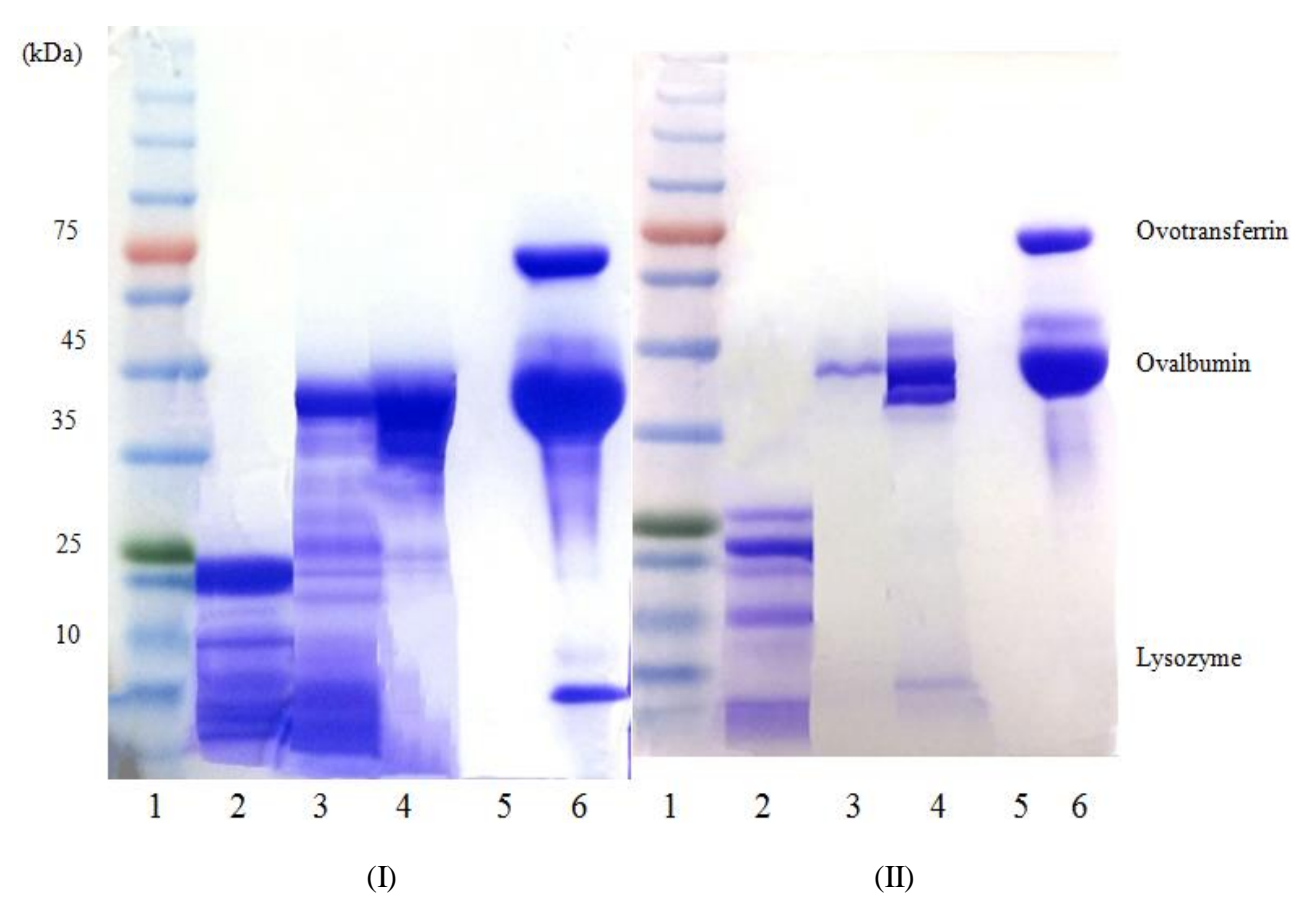

Fig. 1: SDS-PAGE for various egg white hydrolysates and native egg white; (I): Mixture of water-soluble fraction and waterinsoluble fraction. (II): Water-insoluble fraction. Lane 1: molecular size markers. Lane 2: egg white hydrolyzed by Protin NY100®; Lane 3: Egg white hydrolyzed by Thermoase PC10F®; Lane 4: Egg white hydrolyzed by Protease M®; Lane 5: highly hydrolyzed commercial egg white peptides; Lane 6: native egg white

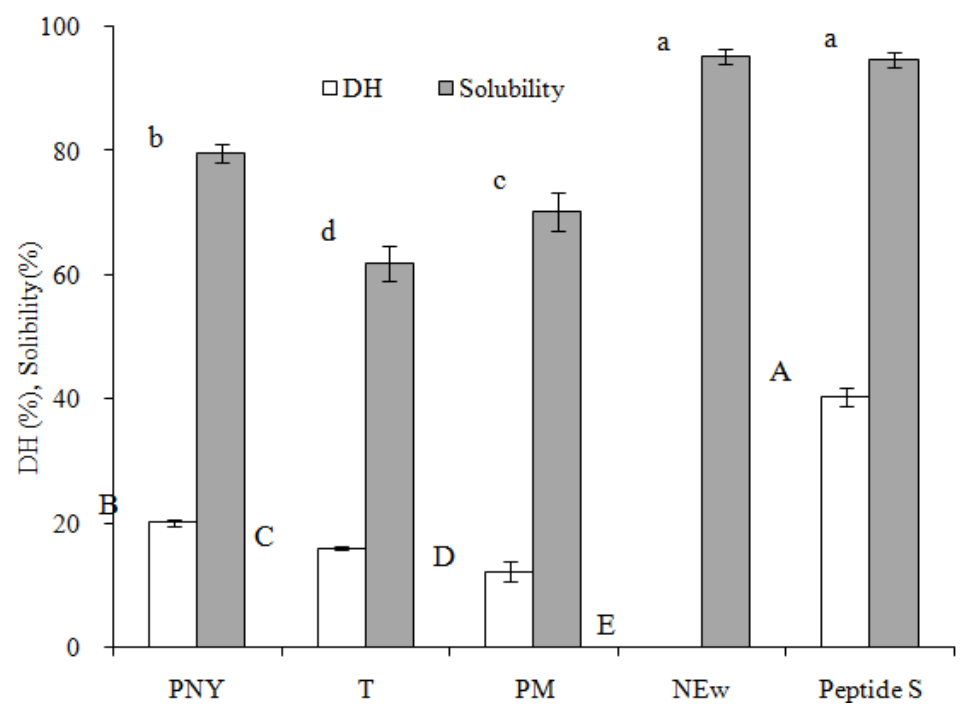

Fig. 2: Solubility and degree of hydrolysis (DH) of egg white hydrolysates. PNY: Egg white hydrolyzed by Protin NY100 ${ }^{\circledR}$; T: Egg white hydrolyzed by Thermoase $\mathrm{PC} 10 \mathrm{~F}^{\circledR}$; PM: Egg white hydrolyzed by Protease $\mathrm{M}^{\circledR}$; NEw: native egg white; Peptide S: highly hydrolyzed commercial egg white peptides. Means within column with no common superscript differ significantly $(\mathrm{p}<0.05)$

different degree of hydrolysis, result showed that the fractions of molecular weight lower than $3 \mathrm{kDa}$ by ultrafiltration of the hydrolysate (DH of 12.4\%) exhibited the highest antioxidant, EW hydrolysate with different DH have different bioactive and functional properties, therefore, EW hydrolysate by controlled hydrolysis may be an useful ingredient in food and nutraceutical applications with potential bioactive properties.

Profiles of color characteristics of different samples: Meat color is one of the most important indexes 
Adv. J. Food Sci. Technol., 14(5): 148-154, 2018

Table 2: Profiles of color characteristics of pork slices treated by different samples

\begin{tabular}{|c|c|c|c|c|c|c|}
\hline Sample & PNY & $\mathrm{T}$ & PM & Control & NEw & Peptide S \\
\hline \multicolumn{7}{|c|}{ Original meat } \\
\hline $\mathrm{L}^{*}$ & $35.92 \pm 0.18$ & & & & & \\
\hline$a^{*}$ & $11.27 \pm 0.45$ & & & & & \\
\hline$b^{*}$ & $6.86 \pm 0.33$ & & & & & \\
\hline E & 38.27 & & & & & \\
\hline \multicolumn{7}{|c|}{ After soak } \\
\hline $\mathrm{L}^{*}$ & $38.33 \pm 0.15$ & $38.83 \pm 0.81$ & $39.33 \pm 0.88$ & $45.76 \pm 2.23$ & $38.04 \pm 0.06$ & $36.74 \pm 0.31$ \\
\hline$a^{*}$ & $9.33 \pm 0.58$ & $8.97 \pm 0.77$ & $8.96 \pm 0.62$ & $7.52 \pm 1.37$ & $7.84 \pm 0.05$ & $9.30 \pm 0.44$ \\
\hline$b^{*}$ & $4.31 \pm 0.08$ & $5.24 \pm 1.20$ & $5.25 \pm 0.32$ & $5.97 \pm 0.54$ & $4.72 \pm 0.37$ & $5.05 \pm 0.38$ \\
\hline$\Delta \mathrm{E}$ & 3.46 & 4.05 & 4.42 & 10.57 & 4.56 & 2.80 \\
\hline
\end{tabular}

PNY: Egg white hydrolyzed by Protin NY100 ${ }^{\circledR}$; : Egg white hydrolyzed by Thermoase PC10F ${ }^{\circledR}$ PM: Egg white hydrolyzed by Protease $\mathrm{M}^{\circledR}$; NEw: native egg white; Peptide S: highly hydrolyzed commercial egg white peptides; Control: Meat soaked in only water

Table 3: Relative proportions of metmyoglobin in meat slices soaked in different egg white hydrolysates

\begin{tabular}{llllllll}
\hline Sample & Original Meat & PNY & T & PM & Control & NEw & Peptide S \\
\hline MetMb $(\%)$ & $30.49 \pm 0.83^{\mathrm{d}}$ & $33.24 \pm 0.53^{\mathrm{c}}$ & $34.34 \pm 0.25^{\mathrm{b}}$ & $35.49 \pm 1.25^{\mathrm{a}}$ & $37.40 \pm 0.50^{\mathrm{a}}$ & $35.92 \pm 0.84^{\mathrm{a}}$ & $32.47 \pm 0.78^{\mathrm{c}}$ \\
\hline
\end{tabular}

Table 2, means within column with no common superscript differ significantly $(\mathrm{p}<0.05)$

defining the quality of meat (Lindahl et al., 2001). The measurement of color is usually presented as the resultant of three different values $-L *$ (lightness), $a^{*}$ (redness), $b^{*}$ (yellowness). Changes in $L *, \mathrm{a} *$ and $\mathrm{b} *$ of pork meat slices are shown in Table 2. Photos of meat before soak and after the soak in different solutions were shown in Fig. 4a and 4b, respectively.

Several researchers have already studied the effect of natural anti-oxidative extracted compounds on the ground beef or pork patties. For example, Park and Chin (2010) found that the addition of garlic extracts to pork patties decreased the $\mathrm{pH}$, redness and Thiobarbituric Acid Reactive Substances (TBARS) values.

In Japan, even in the world, grilled pork meat is a quite popular meal, so in the current study, we soaked the pork meat slices into the solution which was with or without EW hydrolysates. After soaking in the solution for $24 \mathrm{~h}$, compared with the control (with water), samples incorporated with NEw or EW hydrolysates showed lower $\Delta \mathrm{E}$. The lowest $\Delta \mathrm{E}$ was observed by samples incorporated with Peptide $\mathrm{S}$ as shown in Table 2 , suggesting that Peptide $S$ has the greatest potential to keep the color stability. Samples soaked in water (Control sample) and NEw samples showed the lowest redness.

The color of meat products is influenced by metmyoglobin percentage in muscle. The myoglobin was changed into oxymyoglobin (light pink color), which could result in brighter red meat and then oxymyoglobin was oxidized into metmyoglobin during storage (Zhang et al., 2016). As myoglobin is a watersoluble protein in meat, when meat is soaked in Control (only with water), the loss of myoglobin led to the most color change $(\Delta E=10.6)$, a significant increase in $L^{*}$ values indicated the light color reduction of meat shown in Table 2. Combined with results shown in Fig. 1 and 2 , Peptide $\mathrm{S}$ possessed higher ORAC value and a quite good solubility, small size of peptide which could be absorbed easily into the center of meat fiber, protects the remaining myoglobin from oxidation.
Relative proportions of metmyoglobin of pork soaked in different EW hydrolysate solutions: Krzywicki's equations have been widely used for estimating the relative proportions of myoglobin redox forms in aqueous solution (Viriyarattanasak et al., 2011). Relative proportions of metmyoglobin of pork soaked in different EW hydrolysate solutions were shown in Table 3. Myoglobin has three natural colors (deoxymyoglobin, oxymyoglobin and metmyoglobin) depending on its exposure to oxygen and the chemical state of the iron, metmyoglobin is a compound formed from myoglobin by oxidation of the ferrous to the ferric state with essentially ionic bonds. It was obvious to observe that after $24 \mathrm{~h}$, the relative proportion of metmyoglobin increased, especially in the control sample which was soaked in only water, it demonstrated that although being soaked in solutions, the oxidation of myoglobin still occurred. Results showed that the lowest metmyoglobin proportion was found in the pork treated by small EW peptide- Peptide $\mathrm{S}$, it showed a relatively higher ORAC value than the other samples. Regardless of the presence of ovotransferrin shown by SDS-PAGE, PM and NEw showed a similar effect on the proportion of metmyoglobin in the pork. In general, the result of metmyoglobin proportion is in good agreement with the ORAC values shown in Fig. 3, suggesting that EW hydrolysates can potentially be used as preservatives in meat products.

\section{CONCLUSION}

This study aimed to study the potential of egg white hydrolysate as a natural antioxidant for the preservation of pork meat slices. Different egg white hydrolysates samples were prepared; then different characteristics such as solubility, molecular size and ORAC values were evaluated. Meat slices were soaked in egg white hydrolysates stored at $4^{\circ} \mathrm{C}$ for $24 \mathrm{~h}$. Small peptide-Peptide $\mathrm{S}$ (with molecular weight lower than 10 $\mathrm{kDa})$ showed the best ORAC value $(389 \mu \mathrm{mol} \mathrm{TE} / \mathrm{g})$ 


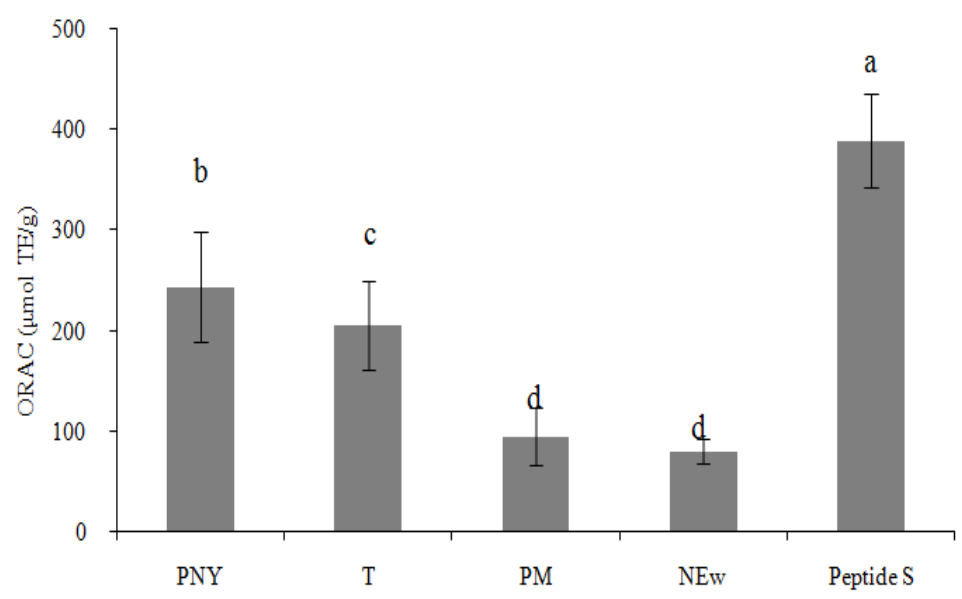

Fig. 3: ORAC values of different samples (Fig. 2). Means within column with no common superscript differ significantly $(\mathrm{p}<0.05)$

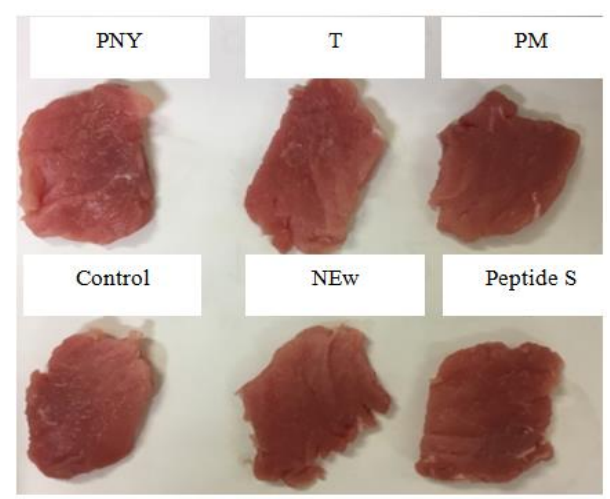

(a) Original meat

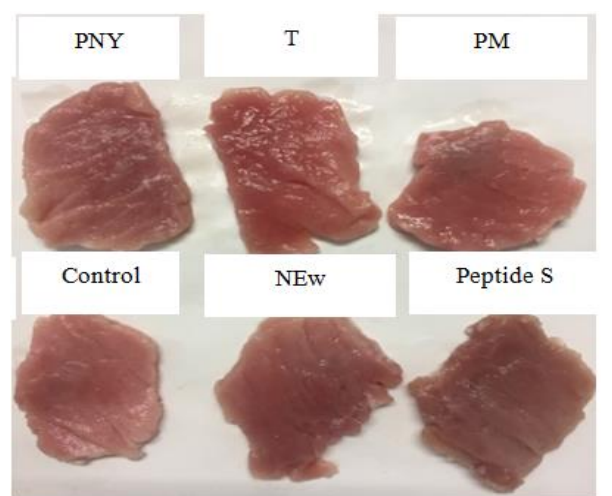

(b) Meat after soaking for $24 \mathrm{~h}$

Fig. 4: Photos of meat before soak; (a): and after soak; (b): in different solutions (Fig. 2)

and excellent water solubility, could inhibit the color change in treated pork slices. Moreover, it was demonstrated that egg white hydrolysates were generally better than Control (with water) in improving color stability during storage time. Therefore, it can be concluded that egg white hydrolysate can be used as a natural antioxidant in meat. This study may have potential implication for developing nutrition enhanced meat products, thanks to the nutritionally complete with a good balance of essential amino acids in egg white proteins.

\section{REFERENCES}

Abeyrathne, E.D., H.Y. Lee and D.U. Ahn, 2013. Egg white proteins and their potential use in food processing or as nutraceutical and pharmaceutical agents--a review. Poult. Sci., 92(12): 3292-3299.

Bkhairia, I., B.S.R. Ben Salama, R. Nasri, M. Jridi, S. Ghorbel and M. Nasri, 2016. In-vitro antioxidant and functional properties of protein hydrolysates from golden grey mullet prepared by commercial, microbial and visceral proteases. J. Food Sci. Technol., 53(7): 2902-2912.
Cheison, S.C., S.B. Zhang, Z.Z. Wang and S.Y. Xu, 2009. Comparison of a modified spectrophotometric and the $\mathrm{pH}$-stat methods for determination of the degree of hydrolysis of whey proteins hydrolysed in a tangential-flow filter membrane reactor. Food Res. Int., 42(1): 91-97.

Chen, C., Y.J. Chi, M.Y. Zhao and W. Xu, 2012. Influence of degree of hydrolysis on functional properties, antioxidant and ACE inhibitory activities of egg white protein hydrolysate. Food Sci. Biotechnol., 21(1): 27-34.

Church, F.C., H.E. Swaisgood, D.H. Porter and G.L. Catignani, 1983. Spectro-photometric assay using o -phthaldialdehyde for determination of proteolysis in milk and isolated milk proteins 1. J. Dairy Sci., 66: 1219-1227.

Darrouzet-Nardi, A., M.P. Ladd and M.N. Weintraub, 2013. Fluorescent microplate analysis of amino acids and other primary amines in soils. Soil Biol. Biochem., 57: 78-82.

Davalos, A., C. Gómez-Cordovés and B. Bartolomé, 2004. Extending applicability of the oxygen radical absorbance capacity (ORAC-Fluorescein) assay. J. Agr. Food Chem., 52(1): 48-54. 
Faustman, C., M.C. Yin and D.B. Nadeau, 1992. Color stability, lipid stability, and nutrient composition of red and white veal. J. Food Sci., 57(2): 302-304.

Hashemi, G.H., E. Ziaee, M.H. Eskandari and S.M. Hosseini, 2017. Characterization of basil seed gum-based edible films incorporated with Zataria multiflora essential oil nanoemulsion. Carbohyd. Polym., 166: 93-103.

Hood, D.E., 1980. Factors affecting the rate of metmyoglobin accumulation in pre-packaged beef. Meat Sci., 4(4): 247-265.

Ibrahim, H.R., Y. Sugimoto and T. Aoki, 2000. Ovotransferrin antimicrobial peptide (otap-92) kills bacteria through a membrane damage mechanism. Biochim. Biophys. Acta, 1523(3): 196-205.

Ibrahim, H.R. and T. Kiyono, 2009. Novel anticancer activity of the autocleaved ovotransferrin against human colon and breast cancer cells. J. Agr. Food Chem., 57(23): 11383-11390.

Ismail, H.A., E.J. Lee, K.Y. Ko and D.U. Ahn, 2009. Fat content influences the color, lipid oxidation, and volatiles of irradiated ground beef. J. Food Sci., 74(06): 432-440.

Jun, L.B., D.G. Hendricks and D.P. Cornforth, 1999. A comparison of carnosine and ascorbic acid on color and lipid stability in a ground beef pattie model system. Meat Sci., 51(3): 245-253.

Kim, S.J., S.C. Min, H.J. Shin, Y.J. Lee, A.R. Cho, S.Y. Kim and J. Han, 2013. Evaluation of the antioxidant activities and nutritional properties of ten edible plant extracts and their application to fresh ground beef. Meat Sci., 93(3): 715-722.

Kumar, Y., D.N. Yadav, T. Ahmad and K. Narsaiah, 2015. Recent trends in the use of natural antioxidants for meat and meat products. Compr. Rev. Food Sci. F., 14(6): 796-812.

Laemmli, J.K., 1970. Sds-polyacrylamide gel electrophoresis of protein. Nature, 2: 680-685.

Lindahl, G., K. Lundström and E. Tornberg, 2001. Contribution of pigment content, myoglobin forms and internal reflectance to the colour of pork loin and ham from pure breed pigs. Meat Sci., 59(2): 141-151.

Lynch, N.M., C.L. Kastner, D.H. Kropf and J.F. Caul, 1986. Flavor and aroma influences on acceptance of polyvinyl chloride versus vacuum packaged ground beef. J. Food Sci., 51(2): 256-267.

Mansour, E.H. and A.H. Khalil, 2000. Evaluation of antioxidant activity of some plant extracts and their application to ground beef patties. Food Chem., 69(2): 135-141.
Markwell, M.A.K., S.M. Haas, L.L. Bieber and N.E. Tolbert, 1978. A modification of the Lowry procedure to simplify protein determination in membrane and lipoprotein samples. Anal. Biochem., 87(1): 206-210.

Miguel, M. and A. Aleixandre, 2006. Antihypertensive peptides derived from egg proteins. J. Nutr., 136(6): 1457-1460.

Moon, S.H., J.H. Lee, Y.J. Lee, K.H. Chang, J.Y. Paik et al., 2013. Screening for cytotoxic activity of ovotransferrin and its enzyme hydrolysates. Poult Sci., 92(2): 424-434.

Nasri, R., I. Younes, M. Jridi, M. Trigui, A. Bougatef et al., 2013. ACE inhibitory and antioxidative activities of Goby (Zosterissessor ophiocephalus) fish protein hydrolysates: Effect on meat lipid oxidation. Food Res. Int., 54(1): 552-561.

Ou, B., M. Hampsch-Woodill and R.L. Prior, 2001. Development and validation of an improved oxygen radical absorbance capacity assay using fluorescein as the fluorescent probe. J. Agr. Food Chem., 49(10): 4619-4626.

Park, S.Y. and K.B. Chin, 2010. Evaluation of preheating and extraction solvents in antioxidant and antimicrobial activities of garlic, and their application in fresh pork patties. Int. J. Food Sci. Tech., 45(2): 365-373.

Pigott, R.S., P.B. Kenney, S. Slider and M.K. Head, 2000. Formulation protocol and dicationic salts affect protein functionality of model system beef batters. J Food Sci., 65(7): 1151-11154.

Shahidi, F., 2000. Antioxidants in food and food antioxidants. Nahrung, 44(3): 158-163.

Ünal, K., A.S. Babaoglu and M. Karakaya, 2014. Effect of oregano, sage and rosemary essential oils on lipid oxidation and color properties of minced beef during refrigerated storage. J. Essent. Oil Bear. Pl., 17(5): 797-805.

Viriyarattanasak, C., N. Hamada-Sato, M. Watanabe, K. Kajiwara and T. Suzuki, 2011. Equations for spectrophotometric determination of relative concentrations of myoglobin derivatives in aqueous tuna meat extracts. Food Chem., 127(2): 656-661.

Watkins, B.A., 1995. The Nutritive Value of the Egg. In: Stadelman, W.J. and O.J. Cotterill (Eds.), Egg Science and Technology. The Haworth Press Inc., New York.

Zhang, X., D. Li, Q. Meng, C. He and L. Ren, 2016. Effect of mulberry leaf extracts on color, lipid oxidation, antioxidant enzyme activities and oxidative breakdown products of raw ground beef during refrigerated storage. J. Food Qual., 39(3): 159-170. 